\title{
Clinical use and control of the dispensing of thalidomide in Brasilia-Federal District, Brazil, from 2001 to 2012
}

\author{
Uso clínico e controle sobre a dispensação de talidomida \\ em Brasília-DF, Brasil, de 2001 a 2012
}

Francisco José Roma Paumgartten ${ }^{1}$

Nair Ramos de Souza ${ }^{1}$

${ }^{1}$ Laboratório de

Toxicologia Ambiental, Escola Nacional de Saúde Pública, Fundação Oswaldo Cruz. Av. Brasil 4036/101, Manguinhos. 21.040-361 Rio de Janeiro RJ Brasil. paum@ensp.fiocruz.br

\begin{abstract}
The use of thalidomide was never discontinued in Brazil where it is prescribed for leprosy type 2 reaction. Babies with birth defects compatible with the thalidomide embryopathy phenotype were born after 1965, an indication that control on drug dispensing and use failed in the country. The article reports data on thalidomide dispensing and clinical uses in the Federal District in 2011/12, when new rules were put into effect, and data on drug dispensing and use obtained ten years earlier. It was found that the number of patients making use of thalidomide declined from 819 in 2001 to 369 in 2011/12. Leprosy accounted for over $70 \%$ of prescriptions in both time periods analyzed in this study. In the same time interval, however, use for lupus erythematosus decreased from 13.7 to $4.9 \%$, while that for multiple myeloma increased from 2.9 to $20.3 \%$ of all prescriptions. Thalidomide prescription for the remaining approved indications was far less frequent, and so was the use for off label indications that accounted for $<1 \%$ of prescriptions in 2001 and 2011/12. Registration of prescribing doctors, patients and dispensing units at the state department of health, apparently rendered this control more effective and reliable.
\end{abstract}

Key words Thalidomide, Off-label uses, Leprosy, Drug control, Multiple myeloma, Lupus erythematosus.
Resumo O uso da talidomida nunca foi interrompido no Brasil, sendo prescrita para tratar a reação tipo 2 da hanseníase. Crianças com defeitos congênitos compatíveis com o fenótipo da embriopatia causada pela talidomida nasceram após 1965, evidenciando que o controle do uso e da dispensação do medicamento falhou no país. $O$ artigo relata dados sobre a dispensação e usos clínicos da talidomida no Distrito Federal em 2011/ 12, quando a nova regulamentação passou a vigorar, e dados sobre a dispensação e uso do medicamento 10 anos antes. Os resultados mostraram que o número de pacientes que usaram talidomida decresceu de $819 \mathrm{em} 2001$ para $369 \mathrm{em}$ 2011/ 12. A hanseníase foi a indicação clínica para mais de $70 \%$ das prescrições nos períodos analisados no estudo. No mesmo período, entretanto, o uso para lupus eritematoso reduziu de 13,7 para 4,9\%, enquanto o uso para mieloma múltiplo cresceu de 2.9 para $20,3 \%$ de todas as prescrições. A prescrição de talidomida para as outras indicações aprovadas foi muito menor, enquanto para indicações não aprovadas correspondeu $a<1 \%$ das prescrições em 2001 e 2011/12. O cadastro dos prescritores, pacientes e unidades dispensadoras na secretaria estadual de saúde, aparentemente tornou esse controle mais eficiente e confiável.

Palavras-chave Talidomida, Uso para indicações não aprovadas, Hanseníase, Controle de medicamentos, Mieloma múltiplo, Lupus eritematoso 


\section{Introduction}

Thalidomide was developed by a German pharmaceutical industry (Chemie Grünenthal), and entered the market as a revolutionary sedative drug in mid $1950 \mathrm{~s}^{1-6}$. Contrasting to tranquilizers and sleeping pills available till then, such as barbiturates and bromides, thalidomide was regarded as a "completely" safe medicine and thus it was sold over-the-counter. According to Chemie Grünenthal researchers, they "could not find a dose high enough to kill a rat". Owing to its anti-anxiety effects and apparent safety compared to barbiturates, allied to an aggressive strategy of marketing, new drug sales rapidly grew up and spread worldwide ${ }^{1-6}$.

Consumers' confidence in the new drug safety, however, was dramatically shaken by sporadic reports on the occurrence of a peripheral neuropathy, and by an unprecedented outbreak of severe congenital malformations ${ }^{7}$. In November 1961, Widukind Lenz, a German physician, reported in a conference that the on going outbreak of phocomelia (limb pre-axial reduction) and amelia (absence of limbs), previously identified in the medical literature as extremely rare birth defects, was associated with maternal consumption of thalidomide during the first trimester of pregnancy ${ }^{2,3,7,8}$. Similar observations made in Australia ${ }^{9}$ and England ${ }^{10}$ confirmed Lenz's pioneering report on the association of thalidomide intake by pregnant women and limb reduction defects. Within a few weeks after the initially reported cases, thalidomide was withdrawn from German and British markets. In Brazil, Belgium, Canada, Italy, Japan and a few other countries, however, thalidomide sales continued for several months thereafter ${ }^{2,3}$. Babies with a thalidomide embryopathy phenotype, born more than nine months after it had been banned in Germany, were considered by Lenz as "avoidable cases", a number of which were born in Brazil and Japan. Lenz estimated that between 5000 and 7000 thalidomide embryopathy cases, $>3000$ of which in Germany alone, occurred until 1966. Some malformations (e.g. heart defects) caused by thalidomide eventually result in prenatal or early postnatal deaths with a 40 to $70 \%$ survival rate giving an overall estimate of $>10000$ affected babies ${ }^{2-4}$.

Although it was banned in almost all countries in mid 1960s, use of thalidomide has never been completely discontinued in Brazil ${ }^{11}$. This long history of thalidomide use resulted from an unexpected new therapeutic indication. In 1965, Jacob Sheskin noted that thalidomide ameliorated symptoms of erythema nodosum leprosum (ENL), or Hansen disease type 2-reaction, a serendipitous finding that was further confirmed by several controlled clinical trials ${ }^{12}$. Owing to its efficacy to treat ENL, and the high prevalence of Hansen disease, in Brazil thalidomide is listed as an essential drug.

Avoidable cases of thalidomide embryopathy born in Brazil after 1965 remained almost unnoticed until mid $1990 s^{5,11}$. In 1994, the NGOs MORHAN (Movement for Integration of People with Hansen Disease) and ABPST (Association of People with Thalidomide Syndrome) announced that after an active search they had found 61 people born after 1965 with birth defects compatible with prenatal exposure to thalidomide $e^{5,11}$. A study by Castilla et al confirmed the occurrence of at least 33 post 1965 cases of thalidomide embryopathy in Brazil ${ }^{13}$.

In mid 1990s, interest in thalidomide reemerged worldwide thanks to new light shed on its anti-inflammatory (anti-TNF $\alpha$ ) properties and to a clinical trial showing that it brought a significant clinical benefit to multiple myeloma patients resistant to conventional therapies ${ }^{14,15}$.

Reacting to the emergence of new therapeutic indications and the uncovering of several post 1965 cases of thalidomide-compatible birth defects, the Brazilian Ministry of Health issued a regulation imposing a strict control on the production, dispensing and prescription of thalidomide. New rules issued in 1997 forbade prescribing thalidomide to women in childbearing age (i.e., from menarche to menopause), except in very special circumstances and under strictly controlled conditions ${ }^{16}$. Afterwards, in 2003, Brazilian Congress passed a law (Federal Law 10.651, April 16th, or "Thalidomide Law") that prohibited thalidomide sale by commercial pharmacies and additionally stated that it can only be dispensed through programs qualified by the federal health authority (i.e., Ministry of Health $)^{17}$. The federal programs through which thalidomide can be dispensed are Hansen Disease, Sexually Transmitted Diseases / AIDS (i.e., aphthous ulcers in AIDS patients) and Chronic Degenerative Diseases (lupus erythematosus and Graft versus Host Disease) $(1997)^{16}$. Moreover, clinical guidelines for using thalidomide in graft versus host disease, lupus erythematosus and multiple myeloma were published in $2002^{18}$.

After more stringent rules on dispensing and clinical use were introduced in 1997, no new case of thalidomide birth defect came to surface until $2005^{11}$. Nonetheless, a new case was described in 
2005 (a male born to a woman who used thalidomide for ENL) and three other cases in 2006, a female born to a woman who took the drug for ENL, and male twins born to a 17-year-old woman who took pills prescribed to her mother, a patient with multiple myeloma ${ }^{19}$. The outcome of a proactive surveillance of cases identified two babies with a thalidomide embryopathy phenotype born in 2007, a female and a male infant ${ }^{20}$. In both cases, however, mothers denied any use of thalidomide during pregnancy ${ }^{20}$. A baby born in Maranhão state in 2010 is so far the most recent case reported to the Ministry of Health (Department of Epidemiological Surveillance / Hanseniasis Control Program, and National Agency of Health Surveillance - Anvisa). A female baby with bilateral upper and lower limb reduction defects was born to a mother who used thalidomide when pregnant to treat type 2-reaction (ENL) painful symptoms ${ }^{21}$.

In 2011, a new regulation on thalidomide control, a draft proposal of which underwent a long public consultation, was finally put into effect by Anvisa $^{22}$. Overall, the new regulation made control on dispensing and prescription apparently more efficient and established rules to authorize thalidomide dispensing if it is prescribed for an off-label indication. It is noteworthy that, before the new regulation was enforced, thalidomide dispensing could only occur through aforementioned Ministry of Health programs and thus off label use was virtually impossible. In this article we report and analyze data on thalidomide dispensing, and prescription for approved and off label indications in Brasilia, DF, before (in 2001) and after (in 2011-12) the new regulation was enforced.

\section{Methods}

Federal district (DF) is the unit (state) of federation where is located Brasilia, the capital of Brazil. It is a square shaped unit of $5,789,16 \mathrm{~km}^{2}$ $(0.06 \%$ of country's area) located in the geographic center of Brazil where, according to 2010 demographic census, 2.570 .160 people live. Although sharing common characteristics with other areas of the country, Federal District can be regarded as an atypical state, the inhabitants of which have an average standard of living score higher than that of people living in most cities and regions of the country. In 2002, one of us (NRS) undertook - as part of a Master degree dissertation research - an active search for data on the control of thalidomide dispensing and prescription in the archives of the Federal District department of health. All documents then required for thalidomide dispensing (prescription notifications, patient information terms, and physician responsibility terms) found in the files of the DF department of health were analyzed and recovered data were organized in tables. So far, the aforementioned data has remained unpublished. In 2011, federal health authority (Anvisa) issued new rules regarding thalidomide dispensing and clinical use that opened a door for drug dispensing for off label indications ${ }^{22}$. One year after new rules were put into effect data for dispensing and prescription during previous 12 months were obtained from the Federal District department of health and Anvisa as well.

\section{Results and Discussion}

\section{Control on thalidomide dispensing in 2001 and 2011/12}

As shown in Table 1, in the Federal District (Brasilia) thalidomide was prescribed and dispensed for 819 patients in 2001. The number of patients who received thalidomide from registered dispensing units dropped to 369 patients (receiving together a total of 24,520 tablets of 100 mg each) during the first year of new rules enforcement. In 2011/12, 17 thalidomide-dispensing units were registered at the state department of health, and prescriptions were dispensed either through public health clinic (46\%) or hospital (54\%) pharmacies. Ten years earlier, in 2001, registration of dispensing units was not required. Nonetheless, an analysis of documents retained at the Federal District department of health revealed that $68 \%$ of thalidomide prescriptions were dispensed at hospital pharmacies and only $2 \%$ at public health clinics, while the place where it was dispensed was not recorded in nearly $30 \%$ of cases (Figure 1).

The absence of required documents in the files of the state department of health seemed to indicate that health authorities control on thalidomide dispensing was rather weak in 2001. For nearly $13 \%$ of patients to whom thalidomide was dispensed in 2001, prescription notifications were not found, nor were found the signed patient information term and physician's responsibility term in 73 and $14 \%$ of cases, respectively (Table 2 ). Since sex and age of patients were recorded, archived documents revealed that during 2001 
Table 1. Clinical use and dispensing of thalidomide in Brasilia, DF, Brazil, in 2001 and from June 2011 to May 2012.

\begin{tabular}{|c|c|c|c|c|c|}
\hline Clinical indication & $\begin{array}{c}\text { ICD } \\
10\end{array}$ & $\begin{array}{c}2001^{*} \\
(12 \mathrm{mo})\end{array}$ & $\begin{array}{c}2011-12 \\
(12 \mathrm{mo})\end{array}$ & $\begin{array}{l}2011^{* *} \\
(7 \mathrm{mo})\end{array}$ & $\begin{array}{l}2012^{* *} \\
(5 \mathrm{mo})\end{array}$ \\
\hline HIV infection (AIDS) & B23.8 & $10(1.2)$ & $0(0.0)$ & $0(0.0)$ & $0(0.0)$ \\
\hline Hansen's disease (leprosy) & A30 & $596(72.8)$ & $273(73.9)$ & $166(75.5)$ & $107(71.8)$ \\
\hline Systemic / discoid lupus erythematosus & M32 & $112(13.7)$ & $18(4.9)$ & $12(5.5)$ & $6(4.0)$ \\
\hline Multiple myeloma & $\mathrm{C} 90$ & $24(2.9)$ & $75(20.3)$ & $41(18.6)$ & $34(22.8)$ \\
\hline Graft vs host disease & Y83 & $0(0.0)$ & $1(0.3)$ & $1(0.4)$ & $0(0.0)$ \\
\hline Behçet's disease & M35.2 & $3(0.4)$ & $0(0.0)$ & $0(0.0)$ & $0(0.0)$ \\
\hline Renal cancer & C64 & $1(0.1)$ & $0(0.0)$ & $0(0.0)$ & $0(0.0)$ \\
\hline Prostate cancer & C61 & $1(0.1)$ & $0(0.0)$ & $0(0.0)$ & $0(0.0)$ \\
\hline Vascular disorder of intestine & K55 & $0(0.0)$ & $1(0.3)$ & $0(0.0)$ & $1(0.7)$ \\
\hline Unknown $^{* * *}$ & - & $72(8.8)$ & $1(0.3)$ & $0(0.0)$ & $1(0.7)$ \\
\hline Total & - & $819(100.0)^{* * * *}$ & $369(100.0)$ & $267(100.0)$ & $149(100.0)$ \\
\hline Females & - & $225(27.0)$ & $126(34.1)$ & $99(37.1)$ & $47(31.5)$ \\
\hline Males & - & $545(67.0)$ & $243(65.9)$ & $168(62.9)$ & $102(68.5)$ \\
\hline Unknown & - & $49(6.0)$ & - & - & - \\
\hline
\end{tabular}

Source: Data recovered by the author (in 2002) from documents retained at department of health of Brasilia-DF (SES/DF) for the whole year of 2001. ${ }^{* *}$ From June to December 2011 and January to May 2012. ${ }^{* * *}$ The clinical indication was not informed in any document archived in the department of health. ${ }^{* * * *}$ Patient's treatment duration (days): 0-30 $=714 ; 35-60=31 ; 90-120=2$; unknown $=12$.

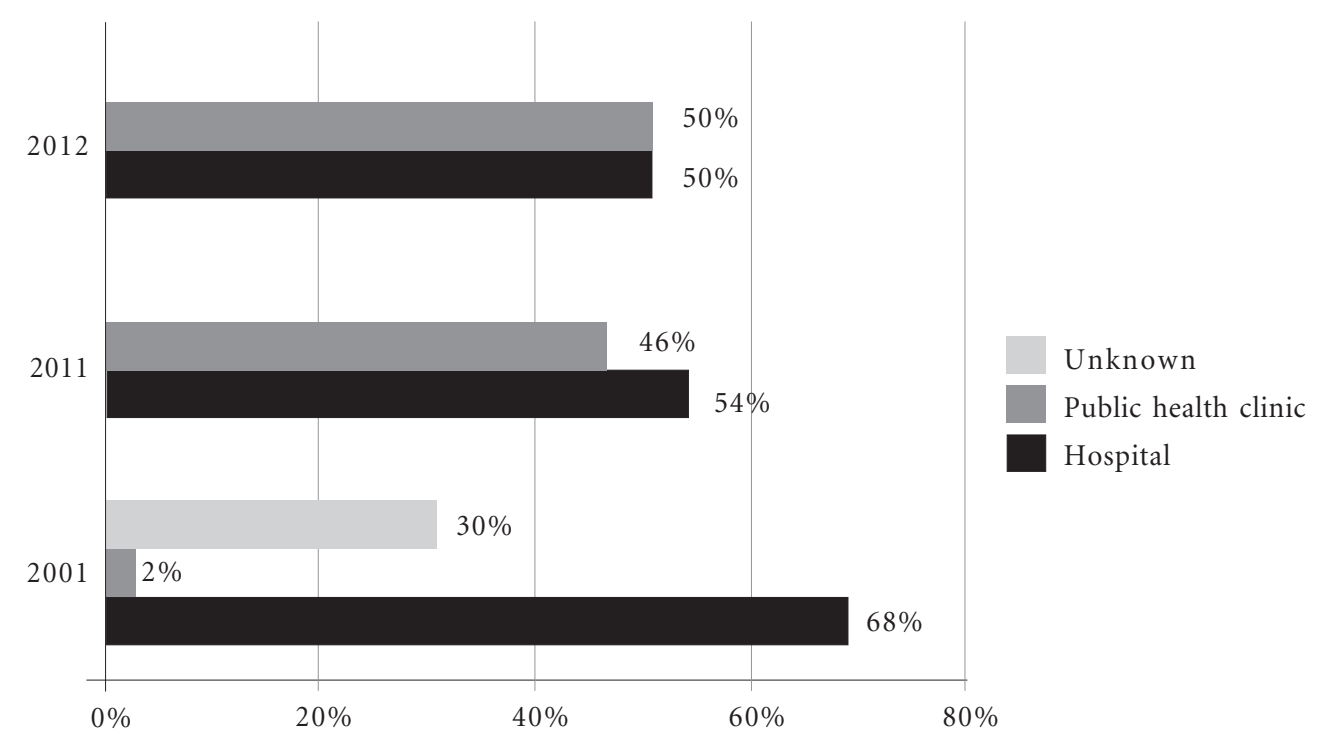

Figure 1. Percentage of prescriptions for thalidomide dispensed at public health clinic (gray bar, PHC) and hospital (black bar, HPT) pharmacies in the Federal District (Brasilia-Brazil) in 2001 (January-December), 2011 (June-December) and 2012 (January-May). Information on the dispensing unit was not found for 246 (30\%, white bar) prescriptions of thalidomide dispensed in 2001. According to records maintained at the DF department of health, thalidomide prescriptions were dispensed to patients in 9 pharmacies (4 PHC, 5 HPT) in 2001 and in 17 previously registered dispensing units (11 PHC, 6 HPT) in 2011/12. The number of prescriptions of thalidomide dispensed to patients were as follows: 2001 : HPT $=557, \mathrm{PHC}=16$, unknown=16; 2011: $\mathrm{HPT}=119, \mathrm{PHC}=101 ; 2012$ : $\mathrm{HPT}=75, \mathrm{PHC}=74$. 
thalidomide was dispensed to 225 women, 172 of which $(76 \%)$ were between 15 and 49 years old, an age group defined by WHO as that of generally fertile women. This is an astonishing finding because, according to rules in effect in 2001, thalidomide prescription to women in childbearing age was forbidden, except when it was absolutely necessary and additional requirements were fulfilled ${ }^{16}$. Requirements to dispense thalidomide to fertile women (WHO age group) enforced in 1997 were as follows: a) the patient must be referred to a treatment unit previously registered at the state or city department of health, b) patient referral by her doctor must be justified by a detailed report using a special form, c) thalidomide use for that particular case has to be approved by the Ethics Committee of the reference unit, and d) reliable contraceptive methods have to be used throughout the treatment period. No indication was found that doctors complied with these requirements in the aforementioned cases of women in childbearing ages receiving thalidomide in $2001^{16}$.

According to the federal law (law 10.651, April $2003)^{17}$ and rules issued by the health authority (Anvisa) in $2011^{22}$, thalidomide prescription and dispensing to women in childbearing age, provided that pregnancy is excluded and effective contraceptive methods are used before and during treatment, is no longer forbidden. During the first 12 months of new rules enforcement in Brasilia-DF (2011-12), physicians who prescribed thalidomide ( 86 doctors) and dispensing units (17) were all registered at the state department of health. Moreover, treated patient records, thalidomide prescription notifications and terms of information and responsibility, currently a single document signed by both the patient and the physician, were all archived as required by new regulations.

\section{Prescription for approved and off label indications}

Although the number of patients who were dispensed prescriptions for thalidomide nearly halved in 10 years (from 819 in 2001 to 369 in 2011/12), ENL (Hansen's disease) remained as the main clinical condition $(>70 \%$ of all prescriptions) for which the drug has been prescribed in the Federal District (Table 1). The absolute and relative number of prescriptions for approved clinical indications other than Hansen disease, however, markedly changed. The absolute number and percentages of prescriptions for lupus erythematosus declined from 112 or $13.7 \%$ in 2001 to 18 or $4.9 \%$ in $2011 / 12$, whereas prescriptions for multiple myeloma grew up from 24 or $2.9 \%$ to 75 or $20.3 \%$ in the same time interval (Table 1). The reduction in use for lupus is possibly explained by the fact that an array of drug options are now available ${ }^{23-25}$, including recently introduced biologics such as a monoclonal antibody (belimumab) that inhibits B lymphocytes activating factor (BAFF) thereby attenuating flares of this autoimmune disease ${ }^{26}$. Thalidomide has been primarily used for cutaneous lupus refractory to other treatments, but many patients relapsed when treatment is withdrawn and side effects such as peripheral neuropathy have also been a problem ${ }^{23-25}$. The increased number of prescriptions for multiple myeloma, on the other side, is consistent with the fact that thalidomide and its analogous drug lenalidomide have changed the treatment paradigm of this neoplastic disease. Combination of thalidomide and dexamethasone has been widely used as induction treatment before autologous stem cell transplantation, while combinations of thalidomide and other drugs have extended progression-free and overall survival in newly diagnosed patients and in patients with refractory-relapsed disease $\mathrm{e}^{27,28}$. Side effects such as peripheral neuropathy and venous thromboembolism remain as major concerns regarding the use of thalidomide to treat multiple myeloma ${ }^{27,28}$.

In Brasilia, thalidomide was prescribed for 10 AIDS patients ( $1.2 \%$ of all prescriptions) in 2001 while no prescription for AIDS was recorded in 2011/12 (Table 1). The drug is primarily used to treat aphthous ulcers that occur in immunodepressed patients ${ }^{29,30}$. Since regular use of antiretroviral therapy (ART) has been found to be inversely related to occurrence of oral lesions, including aphthous ulcers ${ }^{30,31}$, reduced use of thalidomide by AIDS patients possibly reflects the good adherence and widespread access to effective ART. Graft versus Host disease (0.3\% in 2011/ 12 ) and Behçet's disease ( $0.4 \%$ in 2001$)$ accounted for a very small percentage of prescriptions.

Although thalidomide dispensing for conditions other than those approved by the health authority (i.e., Hansen's disease type 2 reaction, aphthous ulcers in AIDS, lupus erythematosus, graft versus host disease and multiple myeloma) was not allowed in 2001, one patient with renal cancer and another with prostate cancer received the drug. Prescription of thalidomide for off label uses accounted for less than $1 \%$ of all prescriptions in 2001. It should be borne in mind, howev- 
er, that control on dispensing was not strictly enforced at that time, and thus it cannot be ruled out that some "unknown" indications referred to in Table 1 ( $8.8 \%$ of all prescriptions) mask use for off label indications that were not recorded as such. It is also possible that some physicians mentioned Hansen disease in the forms when patients were in fact treated for another condition for which thalidomide dispensing was not allowed in 2001. The off label use remained infrequent $(<1 \%)$ in 2011-12 a period during which thalidomide was dispensed for one patient with vascular disease of intestines. Currently, thalidomide dispensing for off label clinical indications is evaluated case by case by a health authority (Anvisa) committee established for that purpose. Doctor's application for off label dispensing is approved depending on the information provided by him/her on the published clinical studies that support the proposed therapeutic use. Since prescribing physicians and dispensing units have to be registered, and information and responsibility forms are archived at the state department of health, unauthorized dispensing and fraud are unlikely to occur under the new rules. It is also of note that medical specialties of registered physicians (Table 3) are consistent with the clinical uses of thalidomide in 2011/12 (Table 1).

\section{Concluding remarks}

In summary, data reported in this study showed that thalidomide use in the Federal District (Brasilia) almost halved in 10 years declining from 819 prescriptions in 2001 to 369 prescriptions during the first 12 months of new regulation enforcement (June 2011- May 2012). Hansen disease (type 2 reaction) remained as the most common clinical indication for thalidomide account-

Table 3. Physicians who prescribe thalidomide and number of dispensing units registered at the Federal District (Brasilia) department of health* in 2011-12.

\begin{tabular}{lc}
\hline Dispensing units & 17 \\
Physicians, No $(\%)$ & $86(100)$ \\
Medical specialty: & $38(44)$ \\
Dermatology & $15(17)$ \\
Internal medicine & $11(13)$ \\
Hematology & $6(7)$ \\
Oncology & $5(6)$ \\
Rheumatology & $5(6)$ \\
Family medicine & $4(5)$ \\
Pediatrics & $2(2)$ \\
Gastroenterology & \\
\hline
\end{tabular}

"Secretaria de Saúde do DF. Physicians who prescribe thalidomide have to be registered at the state department of health otherwise the drug is not given to the patient.

Thalidomide dispensing units (hospitals and public health clinics) also have to be registered at the state department of health.

Table 2. Thalidomide prescription and dispensing in Brasilia in 2001 and the required documents archived at the state department of health: prescription notification for thalidomide, patient information term and physician's term of responsibility.

\begin{tabular}{lrr}
\multicolumn{1}{c}{ Archived documents } & No & $\%$ \\
\hline Complete (03 documents) & & \\
$\quad$ Prescription notification+ information term + responsibility term & 107 & 13.0 \\
Incomplete (only 02 documents found) & 8 & 1.0 \\
$\quad$ Prescription notification + information term & 594 & 72.5 \\
Prescription notification + responsibility term & 0 & 0.0 \\
Information term + responsibility term & 2 & 0.2 \\
Incomplete (only 01 document found) & 105 & 12.9 \\
Prescription notification & 3 & 0.4 \\
Information term & 819 & 100.0 \\
Responsibility term & & \\
Total & 108 & 13.3 \\
Missing documents & 599 & 73.1 \\
Prescription notification & 115 & 14.1 \\
Information term & & \\
Responsibility term & & \\
\hline
\end{tabular}


ing for over $70 \%$ of all prescriptions in both time periods. Use for lupus erythematosus decreased (from 13.7 to $4.9 \%$ of all prescriptions) while use for multiple myeloma markedly increased (from 2.9 to $20.3 \%$ of all prescriptions) from 2001 to 2011/12. Thalidomide dispensing for off label indications, on the other side, accounted for less than $1 \%$ of all prescriptions in both periods.

Analysis of prescription notifications, and patient information and medical responsibility terms archived at the state (DF) department of health revealed that control on thalidomide dispensing was deficient in 2001. Although thalidomide was strictly forbidden for women in child- bearing age, $76 \%$ of women who received the drug in 2001 were 15 to 49 years old (i.e., between menarche and menopause). Additional evidence that control on thalidomide dispensing was inadequate in 2001 is the fact that, in a high proportion of cases, at least one of required documents contained incomplete information or were missing in the archives of the department of health. After new regulation (Anvisa RDC no11/ 2011) was put into effect in May 2011, prior registration of prescribing physicians and dispensing units and a file with patients' data, apparently allowed a more effective and reliable control on thalidomide dispensing and clinical use.

\section{Collaborations}

NR Souza is a doctoral student of the National School of Public Health Sergio Arouca, Fiocruz. She collected, analyzed and tabulated the data and also contributed to writing the manuscript. FJR Paumgartten was her supervisor. He interpreted and discussed the results, and wrote and revised the final version of the manuscript.

\section{Acknowledgments}

The authors gratefully acknowledge Federal District Department of Health (Secretaria de Saúde do DF) director and staff in 2002 and 2012 for allowing access to archived documentation and assistance. Our thanks also go to the National Agency of Health Surveillance (Anvisa). FJRP is recipient of a fellowship from the Brazilian $\mathrm{Na}$ tional Research Council (CNPq). The authors declare no conflict of interest regarding the study. 


\section{References}

1. Maio G. Zur Geschichte der Contergan-Katastrophe im Lichte der Arzneimittelgesetzgebung. Dtsch Med Wochenschr 2001; 126(42):1183-1186.

2. Lenz W. A short history of thalidomide embryopathy. Teratology 1988; 38(3):203-215.

3. Lenz W. A personal perspective on the thalidomide tragedy. Teratology 1992; 46(5):417-418.

4. Calabrese L, Fleischer AB. Thalidomide: current and potential clinical applications. Am J Med 2000; 108(6):487-495.

5. Oliveira MA, Bermudez JA, Souza AC. Talidomida no Brasil: vigilância com responsabilidade compartilhada. Cad Saude Publica 1999; 15(1):99-112.

6. Osorio-de-Castro CGS, Paumgartten FJR Silver LD. O uso de medicamentos na gravidez. Cien Saude Colet 2004; 9(4):987-996.

7. Lenz W, Knapp K. Thalidomide embryopathy. Arch Environ Health 1962; 5:100-105.

8. Lenz W. Thalidomide embryopathy in Germany, 1959-1961. Prog Clin Biol Res 1985; 163C:77-83.

9. McBride WG. Thalidomide and congenital abnormalities - Letter to the Editor. Lancet 1961; 16:1358.

10. Smithells RW. Thalidomide and malformations in Liverpool. Lancet 1962; i:1270-273.

11. Paumgartten FJ, Chahoud I. Thalidomide embryopathy cases in Brazil after 1965. Reprod Toxicol 2006; 22(1):1-2.

12. Sheskin J. Thalidomide in the treatment of lepra reactions. Clin Pharmacol Ther 1965; 6:303-306.

13. Castilla EE, Ashton-Prolla P, Barreda-Mejia E, Brunoni D, Cavalcanti DP, Correa-Neto J, Delgadillo JL, Dutra MG, Felix T, Giraldo A, Juarez N, Lopez-Camelo JS, Nazer J, Orioli IM, Paz JE, Pessoto MA, Pina-Neto JM, Quadrelli R, Rittler M, Rueda S, Saltos M, Sánchez O, Schüler L. Thalidomide, a current teratogen in South America. Teratology 1996; 54(6):273-277.

14. Matthews SJ, McCoy C. Thalidomide: a review of approved and investigational uses. Clin Ther 2003; 25(2):342-395.

15. Tseng S, Pak G, Washenik K, Pomeranz MK, Shupack JL. Rediscovering thalidomide: a review of its mechanism of action, side effects, and potential uses. J Am Acad Dermatol 1996; 35(6):969-979.

16. Brasil. Portaria no 354/MS/SNVS de 15 de Agosto de 1997. Regulamenta o registro, a produção, a comercialização, a exposição à venda, a prescrição e a dispensação dos produtos à base de talidomida. Diário Oficial da União 1997; 18 ago.

17. Brasil. Lei no 10.651 de 16 de Abril de 2003. Dispõe sobre o controle do uso da talidomida. Diário Oficial da União 2003; 17 abr.

18. Brasil. Portaria conjunta no 25 de 30 de Janeiro de 2002. Estabelece protocolos clínicos e diretrizes terapêuticas para: I. Doença Enxerto Contra Hospedeiro (DECH) - Talidomida; II. Lúpus Eritematoso Sistêmico - Talidomida; III - Mieloma Múltiplo Talidomida. Diário Oficial da União 2002; 2 fev.
19. Schuler-Faccini L, Soares RC, de Sousa AC, Maximino C, Luna E, Schwartz IV, Waldman C, Castilla EE. New cases of thalidomide embryopathy in Brazil. Birth Defects Res A Clin Mol Teratol 2007; 79(9):671-672

20. Vianna FS, Lopez-Camelo JS, Leite JC, Sanseverino MT, Dutra Mda G, Castilla EE, Schüler-Faccini L. Epidemiological surveillance of birth defects compatible with thalidomide embryopathy in Brazil. PLoS One 2011; 6(7):e21735.

21. Brasil. Ministério da Saúde (MS). Secretaria de Vigilância em Saúde (SVS) e Agência Nacional de Vigilância Sanitária (Anvisa). Relatório conjunto de investigação de suspeita de embriopatia por talidomida no município de Cajari - Maranhão, Janeiro de 2011. Brasília: SVS-Anvisa; 2001. 26 p.

22. Agência Nacional de Vigilância Sanitária (Anvisa). Resolução Diretoria Colegiada no $11 /$ MS/Anvisa de 22 de Março de 2011. Dispõe sobre o controle da substância talidomida e do medicamento que a contenha. Diário Oficial da União 2011; 27 mar.

23. Pasero G, Marson P. Short story of antirheumatic therapy. VIII. The immunodepressants. Reumatismo 2012; 64(1):44-54.

24. Kuhn A, Ruland V, Bonsmann G. Cutaneous lupus erythematosus: update of therapeutic options part II. J Am Acad Dermatol 2011; 65(6):e195-213.

25. Cortés-Hernández J, Torres-Salido M, Castro-Marrero J, Vilardell-Tarres M, Ordi-Ros J. Thalidomide in the treatment of refractory cutaneous lupus erythematosus: prognostic factors of clinical outcome. Br J Dermatol 2012; 166(3):616-623.

26. Shum K, Askanase A. Belimumab and the clinical data. Curr Rheumatol Rep 2012; 14(4):310-317.

27. Moreau P. The future of therapy for relapsed/refractory multiple myeloma: emerging agents and novel treatment strategies. Semin Hematol 2012; 49(Supl. 1):S33-46.

28. Morabito F, Recchia AG, Mazzone C, Gentile M Targeted therapy of multiple myeloma: the changing paradigm at the beginning of the new millennium. Curr Cancer Drug Targets 2012; 12(7):743-756.

29. Bruyn GA. Thalidomide Celgene Corp. IDrugs 1998; 1(4):490-500.

30. Miziara ID, Araujo Filho BC, Weber R. AIDS and Recurrent Aphthous Stomatitis. Braz J Otorhinolaryngol 2005; 71(4):517-520.

31. Aleixo RQ, Scherma AP, Guimarães G, Cortelli JR, Cortelli SC. DMFT index and oral mucosal lesions associated with HIV infection: cross-sectional study in Porto Velho, Amazonian region - Brazil. Braz J Infect Dis 2010; 14(5):449-456.

Artigo apresentado em 11/04/2012

Aprovado em 18/07/2012

Versão final apresentada em 25/07/2012 